\section{THE MILROY LECTURES ON TYPHOID FEVER.}

PROF. CORFIELD gave the first of his course of Milroy Lectures on typhoid fever at the Royal College of Physicians on Thursday last.

After an introduction, in which he defended the name typhoid fever as that used by Louis and Jenner, and as being the least objectionable name to give to the disease, and pointing out that the name of enteric fever is a bad one, not only because it gives the name to a general disease from a particular lesion, but because it suggests the false idea that the disease is due to that lesion, he proceeded to give a short history of the subject from the beginning of the last century, first introducing a hitherto unknown author, Dr. Christopher Mayr, of Vienna, an unopened copy of whose Latin work on fevers, published in Vienna in 1806 , he had found in the library of the Royal Medical and Chirurgical Society of London. He stated that there is no other copy of this book known in London, whether in the British Museum or anywhere else, and that the leaves had not been separated when he found it. This author gives an admirable classification of fevers into genera and species, the different varieties of typhus forming his second genus, and including typhus fever and the oriental plague, which were confused together until long after that time, the occidental plague or American yellow fever, all of which he regarded as contagious, and three varieties which he regarded as non-contagious and which were evidently, from his excellent description, varieties of typhoid fever.

This author also gave a most interesting disquisition on the contagion and on the causes of these diseases. It is remarkable also to note that he includes phthisis pulmonalis among the fevers, though he does not say whether he regards it as contagious or not.

Dr. Corfield then gave an account of the work and views of MM. Louis, Chomel, Gaultier de Clanbry, Montault, Rochoux, and other French physicians, some of whom considered typhus and typhoid as the same disease and others as different diseases.

After alluding to the work of a number of other investigators, especially Dr. Lombard, of Geneva, and Dr. Shuttuck, of Boston, he gave an account of an important paper, read by Dr $\mathrm{H}$. C. Barlow before the Parisian Medical Society on February 6, I840, on the distinction between typhus and typhoid fevers. In this paper Dr. Barlow described the differences between the two diseases, and decided positively that they were quite distinct from one another.

Two months after this, Dr. Alexander P. Stewart also read a paper on the same subject before the Parisian Medical Society, but, contrary to the opinion generally held, he did not advance the knowledge of the subject in any way by his paper, and, in fact, did not lead us as far as Dr. Barlow had already done.

The work of Prof. Forget, of Paris, on follicular enteritis (even a worse name for the disease than enteric fever) was next alluded to, it being quite clear that Prof. Forget thoroughly understood what typhoid fever was and that it was a different disease from typhus.

Such was the position when Dr. William Jenner (afterwards Sir William Jenner, Bart., G.C.B., president of the Royal College of Physicians) undertook the investigation of the question. As he had been resident medical officer of the London Fever Hospital, he had had an excellent opportunity, of which he made the best use, of observing cases, both of typhus and typhoid fevers, and in 1849 he published his admirable paper on the identity or non-identity of those diseases. He proved to a demonstration that they were different diseases, and in a subsequent paper also proved that without a doubt their causes were different.

It was reserved, however, for Dr. Charles Murchison, in his able paper read before the Royal Medical and Chirurgical Society of London in $185^{8}$, to demonstrate that typhoid fever is caused in some way or other by water, air and soil contaminated with foul organic matters. In his great treatise on the continued fevers of Great Britain, he maintained that the poisons of those diseases were generated de novo; that of typhoid fever from decomposing excrement.

In 1873 , Dr. William Budd produced his masterly work on the disease, proving that "typhoid fever is in its essence a contagious or self-propagating fever."

Dr. Corfield finally quoted from his own paper, "On the alleged Spontaneous Production of the Poison of Enteric Fever,"

NO. I 687 , voL. 65$]$ read before the Epidemiological Society in March, 1874, when he combated the views of Dr. Murchison and maintained that the disease was infectious and had a special poison, which was not generated de novo, but was always derived from a previous case of typhoid fever. The correctness of this view has now been established by the discovery of the organism peculiar to the disease.

\section{VESSELS WITH TURBINE MACHINERY.}

THE introduction of the Parsons marine steam turbine into practice has extended ever since the time the Turbinia showed her marvellous qualities for speed, and was followed by the two torpedo boat destroyers, H.M.S. Viper and H.M.S. Cobra, which broke all previous records with a speed above 35 knots. The next steamer thus equipped was the King Edward, an excursion steamer plying on the Fairlie-Campbeltown route, and being the pioneer vessel belonging to the mercantile marine fitted with turbines, created a considerable interest at the time. The King Edward has now undergone a season's running, and (says Engineering, January 24) in order thoroughly to test her turbine machinery and coal consumption, data have been tabulated from her and also from the Clyde passenger paddle steamer of the same size named The Duchess of Hainilton, thus giving a comparative statement of the two vessels for the "running" throughout the season. The table is as. follows :-

Comparative Statement of Speed, Mileage and Coal Consumption of the Paddle Steamer "Duchess of Hamilton" and the S.S. "King Edward"

\begin{tabular}{|c|c|c|}
\hline & Duchess of Hamilton. & King Edward. \\
\hline $\begin{array}{llll}\text { Total coal } & \ldots & \ldots & \ldots \\
\text { Miles run } & \ldots & \ldots & \ldots \\
\text { Number of days running } & \ldots \\
\text { Number } & \ldots \\
\text { Daily average consumption.. } \\
\text { Average speed } & \ldots & \ldots\end{array}$ & $\begin{array}{l}1758 \text { tons } x_{3} \text { cwt. } \\
\text { 15.604 } \\
8.87 \\
\text { 1x } 1 \\
\text { r5 tons } 17 \text { cwt. } \\
\text { about } 16 \frac{1}{2} \text { knots }\end{array}$ & $\begin{array}{l}\text { r } 429 \text { tons } 16 \mathrm{cwt} . \\
12,116 \\
8: 47 \\
79 \\
\text { r } 8 \text { tons } 2 \text { cwt. } \\
\text { about } 18 \frac{1}{2} \text { knots }\end{array}$ \\
\hline
\end{tabular}

On referring to the above table, it will be seen that the figures of coal consumption per mile are satisfactory, and also the data prove a decided victory for the steam turbine over the reciprocating engines, insomuch as although the King Edward is by far the faster boat, her consumption of coal per mile is almost as low as that of the Duchess of Hamilion. In a previous issue we pointed out that one of the chief advantages gained by the adoption of the turbine was the possible modification in the "model" of the boat, as finer lines could be introduced for speed purposes. The King Edzerd in this respect also, we understand, has given entire satisfaction to her owners, and not unnaturally another boat of the same type, but $2 \mathrm{I}$ feet longer and with a speed of $2 \mathrm{I}$ knots, is being built, the Parsons Marine Steam Turbine Co. being at present engaged on the machinery.

It is also worthy of notice that the class of craft being built with turbine machinery at the present time comprise three high. speed yachts of large size, one being of the torpedo-boat type with water-tube boilers, so, as is pointed out, the turbines will have every opportunity of appearing at their best. The Parsons Company have also a torpedo-boat destroyer with a similar speed to the Viper (not being built to the order of the Admiralty) which we are informed will have a less consumption both in cruising and full speed than any other 30 -knot boat in the Navy.

This vessel, which is named the Velox, was launched by her builders (hull and boilers), Messrs. R. W. Hawthorn, Leslie and Co., on the Tyne on February $\mathrm{I} \mathrm{I}$, and measures $2 \mathrm{IO} \mathrm{ft}$. long, $2 \mathrm{I} \mathrm{ft}$. beam, with a moulded depth of $12 \mathrm{ft}$. $6 \mathrm{in}$., and to guard against "buckKing" she has been specially "stayed" longitudinally. The Velox, to ensure economy at cruising speeds, has fitted in her a novel arrangement of power wherein engines of the ordinary reciprocating type are designed to work in conjunction with, and are coupled direct on to, the steam turbines, the turbines being kept in reserve for the higher speeds only. In considering coal consumption, it will be seen at once that the engine arrangement introduced by $\mathrm{Mr}$. Parsons forms a very important item, because, as in the case of torpedo-boat destroyers, but a small percentage of their steaming is spent on full speed work : and also, as is well known, as all steam engines (steam 
turbines included) do not work so economically when running much below the power for which they are designed. For the long periods on which these boats are simply cruising about, the coal consumed is only that of the two small triple compound reciprocating engines, the steam turbines not being utilised, thus reducing their " cruising" coal consumption to a minimum which, when running at full speed, is only increased by the low consumption derived from the use of the steam turbine.

The marine steam turbine, forming, as it does, "one of the most striking developments in the history of marine engineering," is largely adopted by private enterprise ; but, as Engineering points out, " it is a little surprising that at present no vessel is in progress fitted with turbine machinery and built for the Royal Navy."

\section{MECHANICAL VENTILATORS FOR MINES. ${ }^{1}$}

THIS report is the outcome of a large number of experiments conducted under the directions of a strong committee of eminent mining engineers. Its object was to obtain exact information concerning the relative efficiencies of various ventilating fans. In order to make the comparisons of real value, the experiments were restricted to collieries provided with two fans, each of which could be used in turn; the conditions were therefore identical in each case. Only three kinds of fans were compared, viz., the Guibal, the Schiele and the Waddle, with the result that the Guibal decidedly carried off the palm. But, as pointed out in the report, the conclusions arrived at are not beyond criticism, because the efficiencies were determined in each case by taking the ratio between the so-called "useful effect in air" and the indicated horse-power of the steam-engine used for driving the fan, without knowing how much power was consumed in overcoming the inherent resistance of the engine. Some experiments made in Belgium in 1899 were more satisfactory, because this point was taken into consideration. Here it was found that the Rateau fan had a decidedly higher mechanical efficiency than the Guibal.

The Committee has adhered to Murgue's time-honoured method of comparing the resistance of any given mine to that of an orifice in a thin plate. No doubt the idea of an imaginary "equivalent orifice" has served a useful purpose, but a simpler and plainer way of expressing the amount of resistance is that advocated by Hanarte; he reckons the resistance of a mine by the horse-power required to overcome it, and there is much to be said in favour of his proposal to classify mines according to this system.

Long pages crowded with figures bear testimony to the pains taken by the Committee to fulfil its task, and it is interesting to find that its observations afford a verification of the two fundamental formulæ of centrifugal ventilators. Mr. Walton Brown, the indefatigable secretary of the Institution of Mining Engineers, may be fairly congratulated upon the useful report which he has drawn up.

\section{UNIVERSITY AND EDUCATIONAL INTE LLIGENCE.}

OXForv. - The 233rd meeting of the Junior Scientific Club was beld on February 21. Dr. Hedin, of the Jenner Institute of Preventive Medicine, read a paper, chiefly an account of his recent researches, on "The Proteolytic Enzymes of the Animal Body."

Mr. T. P. Kent, scholar of Christ Church, Oxford, and assistant master at Cranleigh School, Surrey, has been appointed professor of mathematics at Rondebosch College, Cape Town.

In view of the date appointed for the coronation of their Majesties, the day examinations of the Board of Education, South Kensington, arranged to be held during the week ending June 28 , will be held during the week ending July 5 .

AN article on the use of ordnance survey maps in teaching geography, contributed by Sir Archibald Geikie to the February number of the Geographical Teacher, directs attention to the invaluable aid to the study of geography which these maps

1 Report of the Committee of the North of England Institute of Mining and Mechanical Engineers, and the Midland Institute of Mining, Civil an Mechanical Engineers. By Mrs. M. Walton Brown. Transactions of the Institution of Mining Engineers (vol. xvii. pp. $96+x$ vii plates).

$$
\text { NO. I687, VOL, 65] }
$$

afford. In spite of the fact that the maps are adapted to instruction in the most elementary or the most advanced stages of geography, and are so cheap, they are but rarely used, and the geographical lesson is usually conducted in the unintelligent way with which we are all familiar. Hung upon the wall of the schoolroom, the maps encourage the study of home geography in the pupils, and give them facility in map-reading. Attention may then be directed to the information the maps contain as to the configuration or topographical features of the land, the system of contouring, and the method of plotting profiles cr sections across a piece of ground. The teacher can then pass to the intelligent consideration of the causes of the varying physical features of the land, using for this purpose the maps of the Geological Survey, or can derive lessons on the influence of physical features upon the history and progress of the inhabitants of a country. Many other similar uses can be made of the maps, and by adopting them geography may be made a scientific study instead of a jumble of words, figures and phrases. It is to be hoped that Sir Archibald Geikie's paper will be read by every teacher who desires to make the geography lesson a means of cultivating the intelligence. Another paper in the Geographical Teacher which will assist this object is by Mr. A. M. Davies, on the geography of Greater Iondon. Mr. James Bryce's address on the importance of geography in education, delivered at the recent annual meeting of the Geographical Association and already noticed (p. 284), appears in the same number of the nagazine.

A REPORT of the discussion on reform in the teaching of mathematics, which took place at the meeting of the Mathematical Association on January 18, is published in the Mathematical Gazette. Prof. A. Lodge opened the discussion with a paper in which he advocated the introduction of a course of geometry similar to that taken in French schools. The chief points in the French text-books which he desired to see introduced are :-(I) The more orderly arrangement of propositions ; (2) the entire separation of theorems from problems of construction, hypothetical constructions being used in proving a theorem; (3) the closer association of a proposition and its converse when both are true; (4) the adoption of arithmetical notions and algebraic processes; (5) the early introduction of simple loci ; (6) insistence on accurate figures drawn by accurate and practical processes; (7) practice in exercises from the very beginning. In the subsequent discussion, Prof. G. M. Minchin, F.R.S., gave instances of the failure of boys to understand Euclid's language and methods, and also described desirable reforms in the teaching and nomenclature of dynamics and kydrostatics. The discussion was, however, mainly concerned with the teaching of geometry, and the general opinion of the speakers was that demonstrative geometry should be preceded by a course of work with ruler, compasses and protractor, in which simple measurements and constructions formed the chief part. This has been done for many years in Scottish schools and also in some elementary schools in England. One speaker expressed his surprise at the amount of work that could be done with a pencil, ruler, a pair of scissors and a piece of paper, and others referred to the value of illustrations of geometrical truths obtained with similar materials. It seems, however, to have been overlooked that this work has long been part of kindergarten teaching.

\section{SCIENTIFIC SERIAL.}

American Journal of Science, February.-On geometric sequences of the coronas of cloudy condensation, and on the contrast of axial and coronal colours, by C. Barus.-On a new occurrence of sperrylite, by H. L. Wells and S. L. Penfield. A minute quantity of sperrylite, platinum arsenide, was found in a specimen of platiniferous copper ore from the Rambler Mine, Medicine Bow Mountains. Platinum is found in ores from all parts of the mine in quantities varying from ' 06 to $I^{\circ} 4$ ounces per ton. - A cosmic cycle, by F. W. Very. - Studies of Eocene mammalia in the Marsh collection, Peabody Museum, by J. L. Wortman. The present instalment deals chiefly with Patriofelis ferox, and contains a detailed criticism of the views recently expressed by H. F. Osborn. - On a miniature anemo meter for stationary sound waves, by B. Davis. By sufficiently reducing the dimensions of the cups and vanes in the ordinary anemometer, it was found possible to determine the relation between the amplitude of vibration and the rate of rotation in 